\title{
Movements of three alcid species breeding sympatrically in Saint Pierre and Miquelon, northwestern Atlantic Ocean
}

\author{
Delord Karine 1, ${ }^{*}$, Barbraud Christophe 1, Pinaud David 1, Letournel Bruno 2, Jaugeon Baptiste ${ }^{3}$, \\ Goraguer Herle ${ }^{4}$, Lazure Pascal ${ }^{5}$, Lormée Hervé ${ }^{6}$
}

${ }^{1}$ Centre d'Études Biologiques de Chizé, UMR 7372 du CNRS-La Rochelle Université Villiers-en-Bois, France

2 ONCFS, Service départemental de Saint Pierre and Miquelon, Saint Pierre et Miquelon, France

3 Direction des Territoires de l'Alimentation et de la Mer-SAMP, Saint Pierre et Miquelon, France

4 IFREMER Saint Pierre and Miquelon, Saint Pierre et Miquelon, France

5 IFREMER, Univ. Brest, CNRS, IRD, Laboratoire d'Océanographie Physique et Spatiale (LOPS), IUEM

Bres, tFrance

${ }^{6}$ ONCFS, Station ONCFS de Chizé Villiers-en-Bois, France

* Corresponding author : Karine Delord, email address : karine.delord@cebc.cnrs.fr

\begin{abstract}
:
Among seabirds, alcids are particularly sensitive to bycatch in fisheries and oil pollution, yet their distribution at sea remains scarcely known in most of their breeding areas. GPS telemetry data of fifteen individuals of alcids (5 Razorbills 6 Common Murres and 4 Puffins) were analyzed to determine their distribution during the breeding period of 2016 at Saint Pierre and Miquelon Archipelago (SPM). Two analytical methods (threshold and a switching state-space model) were used to identify behavioral modes and foraging areas. We compared foraging movements and estimated the overlap between the species. Distribution and foraging covered an area located between SPM and Newfoundland. Our results revealed that the three species headed northward of their breeding colony, targeting coastal waters. Nonetheless, the three species differed in their habitat distribution as well as in their space-use sharing. There was limited overlap between the foraging zones of the three species and a gillnet fishery targeting Atlantic salmon. Identifying alcids habitat use is imperative to the successful management and survival of these marine species especially since the distribution areas coincide with fishing pressure.
\end{abstract}




\section{Introduction}

Seabirds are one of the most threatened group of birds worldwide and bycatch 
in fisheries is identified as one of the principle causes of population declines (Croxall et al. 2012). Effective management and conservation of seabirds will depend on resolving the spatial distribution of species and vessels fishing efforts (Croxall et al. 2012; Lewison et al. 2014). Identifying important marine areas for seabirds and estimating the overlap with fisheries has been suggested as a method for pinpointing priority areas for seabird conservation (Oppel et al. 2018).

Among seabirds, Alcidae (Murres, Guillemots, Auklets, Puffins and Murrelets) are especially at risk of incidental mortality in fisheries, suffering potentially significant impacts (Regular et al. 2010; Žydelis et al. 2013). Alcids are mainly distributed in northern waters of the Pacific and Atlantic oceans and are particularly prevalent in coastal and neritic areas due to their limited flying capacities (Gaston 2004). Regional-scale investigations revealed that high densities of alcids occur in areas where high abundances of marine organisms are spatially concentrated, typically reflecting areas of high marine productivity and high fishing pressure (Žydelis et al. 2009, 2013). AQ2

Alcids often breed in sympatry and share ecological similarities such as feeding underwater, making them particularly vulnerable to bycatch in gillnet fisheries (Regular et al. 2010). The incidental mortality of alcids in the eastern Canadian Arctic, particularly in the Newfoundland and Labrador gillnet fisheries, is well documented (Piatt and Nettleship 1987; Davoren 2007; Benjamins et al. 2008; Hedd et al. 2016). These gillnet fisheries, responsible for most incidental bycatch of seabirds (Benjamins et al. 2008), were responsible for several thousand seabirds killed annually $(\sim 27,500$ seabirds killed per year during the 1970s and 1980s; Ellis et al. 2013; Žydelis et al. 2013), most of them (80\%) being alcids. (Davoren 2007) identified a high spatial and temporal overlap between Common Murres Uria aalge, and gillnet fisheries for Cod Gadus morhua off NE Newfoundland. The author estimated that 3053-14054 may be changed for 3,053-14,054 guillemots were killed in this hotspot each year, a number which is high compared to the population estimates for the area as a whole (Davoren 2007; Benjamins et al. 2008). This suggests that the regional total bycatch could be higher and that some effects on local populations are likely (Žydelis et al. 2009). Regular et al. (2010) demonstrated that gillnet fisheries were among important factors driving changes in population dynamics of Common Murres breeding in Newfoundland between 1980 and 2006. 
However, despite global knowledge of the at-sea distribution patterns of several alcid populations owing to extensive use of tracking devices during the last decades (i.e. Wanless et al. 1990; Thaxter et al. 2010; Linnebjerg et al. 2013; Pratte et al. 2017), the identification of important marine areas remains insufficiently documented at fine spatial scales for many alcid populations.

The Saint Pierre and Miquelon archipelago (SPM, French Territories), northwestern Atlantic Ocean, was colonized by Common Murres relatively recently and currently hosts $\approx 18,000$ breeding pairs alcids including Razorbills Alca torda, Common Murres and Atlantic Puffins Fratercula arctica (Lormée et al. 2008, 2015). To our knowledge, no study has been conducted to quantify the habitat utilization by this alcid community and its overlap with fisheries. In this study we thus: (1) used GPS devices to identify the foraging movements at-sea of the three species of alcids breeding sympatrically in SPM during the late incubation/early chick-rearing periods; (2) examine the distribution data to isolate important at-sea areas used for foraging; (3) estimate the overlap in distribution between these three species. Based on previous knowledge on the foraging niches of these three species during breeding period (Shoji et al. 2015, 2016; Pratte et al. 2017; Chimienti et al. 2017) we predicted these three species (1) would distribute over relatively short distances $(<50 \mathrm{~km})$ from the colonies and (2) would poorly segregate spatially in their range at-sea considering only one dimension of the trophic niche, the foraging movements.

\section{Materials and methods}

\section{Study area and species}

Data were collected in 2016 at Grand Colombier Island $\left(46^{\circ} 49^{\prime} \mathrm{N}, 56^{\circ} 10^{\prime} \mathrm{E}\right)$, Saint Pierre and Miquelon archipelago (France), in the northwestern Atlantic Ocean. Grand Colombier is a small $(\approx 48$ ha, maximum altitude $149 \mathrm{~m}$ a.s.1.) island situated $\approx 500 \mathrm{~m}$ north of the larger Saint Pierre Island where nearly 6000 maybe change for 6,000 people reside year-round. There is no permanent resident on Grand Colombier whose topography is characterized by a central plateau surrounded by vegetated or rocky slopes and cliffs. Densely vegetated areas (mainly ferns, Dryopteris spinulosa, and graminoids, Deschampsia flexuosa) provide diverse and highly suitable breeding sites for Atlantic Puffins with $\approx 9540$ maybe change for 9,540 breeding pairs (Lormée et al. 2008). Rocky slopes and boulder areas provide favorable breeding sites for Razorbills ( $\approx 1440$ maybe change for 1,440 breeding pairs) and Commun 
Murres $[\approx 7180$ maybe change for 7,180 .... breeding pairs, (Lormée et al. 2015)]. The breeding populations of these two last species dramatically increased during the past years (Lormée et al. 2008, 2015). The trend for the Puffin breeding population is unknown. This island also hosts one of the largest colony ( $\sim 364,000$ breeding pairs) of Leach's Storm-petrels in the northwestern Atlantic (Lormée et al. 2012).

\section{Movements at sea}

We attached GPS to 8 Razorbills, 13 Common Murres and 14 Atlantic Puffins between the 21 st of June and the 2 nd of July 2016. Only breeding birds were equipped with GPS since our main interest was to determine the at-sea distribution during the breeding period. To minimize disturbance and the risk of causing massive breeding failures, we selected individuals situated apart from the main breeding colonies. We used several techniques to catch and recapture the birds. For Common Murres we used a noose at the end of a $5 \mathrm{~m}$ fishing rod for capture and recapture. Razorbills were directly captured by hand and were recaptured by hand or using a carpet noose settled at the entrance of the nest cavity. Puffins were captured by hand within their burrows. Breeding birds were fitted with two different types of devices: $8 \mathrm{~g}$ GPS loggers (CatLog-S, unpackaged i-gotU GT 120; Mobile Action Technology) were deployed on Razorbills and Common Murres, and 5 g GPSUHF waterproof loggers equipped with miniaturized solar panels (PathTrack Fastloc $^{\circledR}$; PathTrack Limited) were deployed on Puffins. The loggers corresponded to $0.9-2.9 \%$ of the body mass $(0.5-1.1 \mathrm{~kg})$, averaging, respectively, $2.5 \%$ for Razorbills, $1.9 \%$ for Common Murres and 1\% for Atlantic Puffins. GPS-UHF loggers allowed downloading the tracking data without recapturing the birds. An autonomous receiving station fitted with a solar panel was settled in the vicinity of the colony where Puffins were equipped. When a Puffin equipped with a GPS-UHF logger came back to its nest, the tracking data were sent wirelessly to the receiving station. Once a day, a computer was connected to the receiving station to download the data. The i-gotU loggers were sealed in heat-shrink plastic tubes. All loggers were attached on the lower back feathers of the birds using waterproof Tesa ${ }^{\circledR}$ tape. Loggers were expected to be removed from the birds at recapture no later than 10 days after deployment or were lost during the next moult if individuals could not be recaptured (Linnebjerg et al. 2013; Shoji et al. 2015). Since Puffins may be prone to nest desertion after capture (Rodway and Montevecchi 1996) we decided not to recapture them. Four Razorbills, 5 Puffins and 1 Common Murre were tagged at the end of incubation; all the 
other birds were tagged while brooding small chicks. The i-gotU loggers were set to record a GPS location at 5 min intervals when speed was lower than $20 \mathrm{~km} / \mathrm{h}$ and at $1 \mathrm{~min}$ intervals when speed was higher than $20 \mathrm{~km} / \mathrm{h}$ to save battery life. All the PathTrack loggers were set to record a GPS location at 5 min intervals. We recorded the breeding success of equipped birds between the time of handling and our last day on the island $(\approx 2$ weeks $)$.

\section{Spatial distribution}

All spatial analyses were performed in R 3.3.1 (R Core Team 2018) using the package 'adehabitatLT0.3.21' and 'adehabitatHR 0.4.14' (Calenge 2006). The tracking data were first resampled at 5 min intervals to allow comparison between the 2 types of loggers using the R package ' $z o o$ '. We identified individual foraging trips ( $>3$ locations) by excluding locations within $500 \mathrm{~m}$ of the colony. Field observations suggested that birds leaving their nest but remaining in the vicinity of the island were washing off, preening and resting, but not foraging (authors' pers. obs.).

For complete trips (all species: $n=83$; Razorbill: $n=28$, Common Murre: $n=$ 33, Puffin: $n=22$ ), over a total of 131 trips, we computed for each trip the following metrics: the maximum distance from the colony (in $\mathrm{km}$ ), the mean speed movement (in $\mathrm{m} / \mathrm{s}$ ), the total distance covered (in $\mathrm{km}$ ), the trip duration (in $\mathrm{h}$ ) and the direction of the most distant location (in radian). We performed bivariate normal kernel density analyses ('kernelUD' function; package 'adehabitatHR 0.4.14') using a smoothing parameter (h) using the ad hoc method 'href' to obtain the utilization distribution (UD) of the distribution locations for each species.

Generalized linear mixed-effects models (GLMMs) were used to model trip metrics and to test for species differences using the 'nlme' and 'lme4' packages (Pinheiro et al. 2013). Species was included as a fixed effect (independent variable). The individual was fitted as a random effect to account for pseudo-replication, as the same individual could provide several values. Residuals were visually tested for normality (through Q-Q plots) and homoscedasticity (using residual vs. dot plots; Zuur et al. 2010) following each statistical test. The error structure approached the normal distribution, and therefore a Gaussian family was selected for all models. Models including all combinations of variables were then tested and ranked using their Akaike information criterion (AIC) values and Akaike weights (Burnham and Anderson 2002). The model with the lowest AIC was considered to be that 
receiving most support from the data. Models separated by a difference in AIC values of $<2$ were assumed to fit the data equally well.

\section{Environmental variables}

Considering the spatial scale at which the birds foraged, only one static (bathymetry) and two dynamic [sea surface temperature (sst) and chlorophyll $a(\operatorname{chl} a)$ ] environmental variables were included in the analysis. Other pertinent environmental variable such as primary productivity was not available at this scale in this area. The bathymetry dataset was obtained from the General Bathymetric Chart of the Oceans database (GEBCO, https://www.gebco.net/) with a resolution of $\sim 1 \mathrm{~km}$ (cell size $930 \mathrm{~m}$ ). The monthly sst and the chla datasets were obtained from the NASA Goddard Space Flight Center, Ocean Ecology Laboratory, Ocean Biology Processing Group with a resolution of $4 \mathrm{~km}$ (Moderate-resolution Imaging Spectroradiometer (MODIS) Aqua Sea Surface Temperature and Chlorophyll a Data; 2014 Reprocessing. NASA OB.DAAC, Greenbelt, MD, USA. https://doi.org/10.5067/aqua/modis_oc.2014.0 (Last access June 2018) provided with time variable by the Integrated Climate Data Center (ICDC, icdc.cen.uni-hamburg.de) University of Hamburg, Hamburg, Germany).

During the study, sea conditions were measured by an ADCP current meter $\left(46^{\circ} 55.8^{\prime} \mathrm{N}, 56^{\circ} 10.3^{\prime} \mathrm{W}\right) 13 \mathrm{~km}$ north of Grand Colombier at a depth of $80 \mathrm{~m}$ and by a wave recorder south of Saint Pierre $\left(46^{\circ} 42.0^{\prime} \mathrm{N}, 56^{\circ} 11.0^{\prime} \mathrm{W}\right)$ including a sea surface temperature sensor. Wind measurements come from the Saint-Pierre airport weather station.

Data from the Atlantic Salmon (Salmo salar) fishery in the French Exclusive Economic Zone (EEZ) were available for the year 2016 (Direction des Territoires, de l'Alimentation et de la Mer-SAMP Database). This is a commercial and recreational fishery using subsurface set gillnet (mesh size: $125 \mathrm{~mm}$ ). Professional fishermen are allowed to use three $360 \mathrm{~m}$ nets and recreational fishermen one $180 \mathrm{~m}$ net. In 2016 the fishery was open from $1 \mathrm{st}$ May to 21st July, which coincides with the three alcid species breeding season. In 2016, 70 recreational and 8 professional salmon fishing licenses were delivered. Each permit holder got assigned to a specific fishing location for the season. The nets are generally set for the entire season, being removed only when the weather conditions are not suitable and when the catch gets too low. In 2016, recreational fishery realized $\sim 80 \%$ of the salmon catch. Cod gillnet fishery operates from August to November and Halibut (Hippoglossus 
hippoglossus) bottom set longline fishery operates throughout fall in SPM EEZ, however, no spatial data were available. From the Atlantic Salmon fishery dataset we further calculated cumulated gridded fishing effort (aggregated fishing effort calculated as the total length of gillnet deployed in $\mathrm{m})$ for a resolution of $\sim 1 \mathrm{~km}$ (cell size $930 \mathrm{~m}$ ).

\section{Overlap analysis}

To investigate whether horizontal space use differed between species we estimated the degree of overlap between the species' range by using the Bhattacharyya's affinity (BA) and the utilization distribution overlap index (UDOI) methods of the 'kerneloverlap' function (Fieberg and Kochanny 2005). The Bhattacharyya's affinity, which ranges from 0 (no similarity between UDs) to 1 (identical UDs), permits to quantify the degree of similarity among UD estimates. The utilization distribution overlap index (UDOI) allows to measure the space-use sharing (Fieberg and Kochanny 2005). Using these metrics we performed a randomization procedure to test the null hypothesis that there was no difference in the spatial distribution between species (Breed et al. 2006). For each species pairwise comparison, we then assessed if the mean observed overlap in the distribution range $(25 \%$, $50 \%, 75 \%$ and $95 \%$ UD) was smaller than that expected by chance. To do so, we calculated a $p$ value as the proportion of randomized overlaps that were smaller or equal to the mean observed overlap value for each pairwise comparison of species (null test). We randomly assigned a species to each individual trip and proceeded with the kernel analysis procedures calculating the overlap based on the BA and UDOI methods. We completed that procedure 1000 times, creating a distribution of 1000 null overlaps of kernels. Since we were testing only if the observed overlap was smaller than random overlap, we considered this a one-tailed test. We used a significance value of $\alpha=0.05$ for one-way pairwise comparisons. Following the null hypothesis above, $p \geq 0.95$ would indicate that the real observed value was at the other end of the randomized distribution (on the right-end tail), indicating significant clustering, or two species overlapping more than expected by chance.

\section{Foraging distribution}

Determining how animals use space from tracking data generally requires inference of likely behaviours from observed movement patterns. To investigate the foraging areas used by species, the tracking locations were 
categorized as occurring during commuting or foraging stage of foraging trips, as commonly used for central-place foragers. Many studies have noted that animals move in at least two modes; one, often labelled "transit", corresponds to relatively fast travel in a consistent direction versus one mingling "searching", "foraging" or "resting", corresponds to slower with higher turning rates movements. Moreover, at the individual level, defining objectively the transition between such behaviors may prove to be difficult (Phillips et al. 2009; Wakefield et al. 2009). To avoid this pitfall, we applied two different methods on the whole dataset in parallel. Firstly, we followed the method used by Wakefield et al. (2009) and Phillips et al. (2009) (hereafter named threshold approach) to determine the stage of the trips at which the transitions occurred at the population level. For each location within a foraging trip the ratio $d_{\text {col }} / d_{\max }$ was calculated, where $d_{\text {col }}$ is the distance from the colony and $d_{\max }$ is the maximum distance from the colony reached during that trip. The ratio $t / t_{\max }$ was also calculated, where $t$ is the time elapsed since the beginning of the trip and $t_{\max }$ is the total trip time. Then, the total variance in $d_{\text {col }} / d_{\max }$ for all locations occurring before $t / t_{\max }$ was plotted against $t / t_{\max }$. The point of inflexion of this curve was determined as well as the value of $t / t_{\max }$ at this point. Tracking locations recorded before this point were classified as those corresponding to the outward trip. Similarly, the total variance in $d_{\mathrm{col}} / d_{\max }$ occurring after $t / t_{\max }$ was plotted against $t / t_{\max }$ and the $t / t_{\max }$ value from which a monotonic decrease of the variance began was recorded. Tracking locations recorded after this point were classified as those corresponding to the return trip, and locations between both points were considered as foraging locations. This method does not allow identifying commuting between different feeding areas during a foraging trip since it is based on time and distance ratios relative to the colony location, departure and return. It only allows identifying when the bird starts to enter in a foraging mode following departure from the colony and when it starts to return to the colony.

Second and in parallel, we employed behavioural categorization from Hidden Markov models (HMMs) to identify areas most intensively used by individuals (Jonsen et al. 2005; Patterson et al. 2009; Langrock et al. 2012). In HMM applications to animal behaviour data, the states of the Markov chain can often naturally be interpreted as proxies for the behavioural states of animals, although there is not necessarily a one-to-one correspondence between nominal HMM states and biologically meaningful behavioural states (Zucchini et al. 2008; Langrock et al. 2012). The HMM approach to 
movement modelling is a discrete state-space model, which focuses on the decomposition of the movement process into distinct underlying states. Such an approach matches our intuitive understanding that most animals' movement is driven by switches in underlying behavioural modes. The HMM approach was applied to the complete dataset (location-latitude/longitude - data) to distinguish behavioural modes. We initially fitted HMM with two or three states to determine the number of states using a model selection approach, but HMM with three states did no converge. We thus only fitted HMM with two states. To examine the relationship between our binary behavioural response variable ("transit" vs. "foraging") and environmental factors (bathymetry, sst and chla), we incorporated these factors as covariates in the models fitted. These environmental variables were used as proxies of the environment, as individuals were probably not responding behaviorally to these covariates but rather to the availability and persistence of their primary prey at specific locations, data which unfortunately do not exist. Models were fitted separately for each species, making the hypothesis that they behave differently and that the transition matrices will be influenced in different ways by covariates. The model selection was done using the generic method Akaike information criterion (AIC) and we used the pseudo-residuals to process the model checking (Michelot et al. 2016). The HMMs were fitted using the $\mathrm{R}$ package 'MoveHMM' (Michelot et al. 2016).

All spatial and statistical analyses were performed in R 3.3.1 (R Core Team 2018).

Estimates are presented as means $\pm 1 \mathrm{sd}$.

\section{Overlap with fishery}

To quantify the overlap between the alcids distribution and the Salmon fishery we overlaid the species foraging distribution identified by the HMM approach $(25 \%, 50 \%, 75 \%$ and $95 \%$ UD) and the fishing effort. That allows to obtain (1) the cumulated fishing effort encountered by each species for each UDs, and (2) the ratio of cells for which there is an overlap calculated as the number of grid cells with fishing effort divided by the total number of grid cells.

\section{Results}

We recovered GPS loggers from 7 Razorbills (recovery rate: $87.5 \%$ ), 7 Common Murres (53.8\%) and downloaded data from 6 Puffins (42.9\%). Data 
were available for 5 Razorbills, 6 Common Murres and 4 Puffins (Table 1). Out of the recovered i-gotU GPS loggers, two recorded very little data (1 Razorbill and 1 Common Murre). None of the tagged Razorbills failed, one (i.e. 7.7\%) Common Murre lost its chick, and 5 Puffins (i.e. 35.7\%, 2 during incubation and 3 during chick rearing) lost their egg or chick. For Puffins, we know that at least one individual lost its GPS since it was observed without the attached unit a few days after deployment. Thus, for Razorbills it is clear that there was no effect of handling or tagging on breeding success. For Common Murres, the failure rate was low and similar to failure rates observed in monitored colonies elsewhere (from 3 to 34\%, Davoren and Montevecchi 2003). For Puffins, we strongly suspect that the relatively low proportion of loggers that gave data was due to insufficient battery charging. Indeed, prolonged burrow attendance by Puffins and heavy cloud cover during the study period probably impeded the miniaturized solar panel to recharge the loggers' batteries. However, the failure rate was relatively high during the 2 weeks period and we cannot exclude that handling and tagging had a negative effect on breeding success with birds deserting their nest. Data were recorded for up to 5 days (Puffins and Common Murres) and 4 days (Razorbills). The devices were recovered after 5 days (Common Murres) and 4 days (Razorbills) following deployment.

\section{Table 1}

Summary of the tracking sample sizes after re-sampling at $5 \mathrm{~min}$ intervals, selecting only trips with three locations or more for three species of sympatrically breeding alcids at the Grand Colombier Island in 2016

\begin{tabular}{|l|l|l|l|l|l|}
\hline Species & $\begin{array}{l}\text { GPS } \\
\text { device }\end{array}$ & Individuals & Locations & Trips & Bathymetry (m) \\
\hline Razorbill & CatLog-S & 5 & 2361 & 38 & $\begin{array}{l}-63.7 \pm 36.3(-7 \\
\text { to }-191)\end{array}$ \\
\hline $\begin{array}{l}\text { Common } \\
\text { Murre }\end{array}$ & CatLog-S & 6 & 2784 & 57 & $\begin{array}{l}-96.5 \pm 53.2(-10 \\
\text { to }-298)\end{array}$ \\
\hline Puffin & PathTrack & 4 & 869 & 36 & $\begin{array}{l}-87.1 \pm 60.8(-8 \\
\text { to }-293)\end{array}$ \\
\hline
\end{tabular}

One trip corresponds to one voyage at-sea by an individual between departure and return to the colony

AQ3

The tagging effort resulted in tracking data for fifteen alcids (5 Razorbills, 6 
Common Murres and 4 Puffins) that utilized a zone between SPM and Newfoundland (Figs. 1b, 2), with a total of 131 trips (Table 1). Breeding alcids distributed mainly in the French EEZ (81.4\% of locations) but overlapped slightly with the Canadian EEZ (18.6\% of locations). Alcids movements covered a relatively small area from the coast to relatively shallow waters (mainly < 200 m; Online Resource 1). Razorbills, Common Murres and Puffins headed principally northward of the breeding colony to forage. During a foraging trip, Puffins tended to cover larger distances at-sea (36.4 \pm $30.3 \mathrm{~km})$ and reached more distant $(19.5 \pm 14.4 \mathrm{~km})$ areas compared to Razorbills (distance covered: $11.1 \pm 10.2 \mathrm{~km}$; maximum range: $21.4 \pm$ $21.0 \mathrm{~km}$ ) and Common Murres (distance covered: $9.9 \pm 7.3 \mathrm{~km}$; maximum range: $19.6 \pm 16.2 \mathrm{~km}$ ) (Table 2 ).

\section{Fig. 1}

a Map and bathymetry (black line) south-west of Newfoundland, boundary of Exclusive Economic Zones (blue line) is shown. b Maps showing the individual raw location data of three species of alcids (green: Razorbill, $n=5$ individuals; red: Common Murre, $n=6$; blue: Puffin, $n=4)$ breeding on Grand Colombier Island (black triangle), Saint Pierre and Miquelon archipelago, northwestern Atlantic. Boundary of Exclusive Economic Zones is shown (white line)
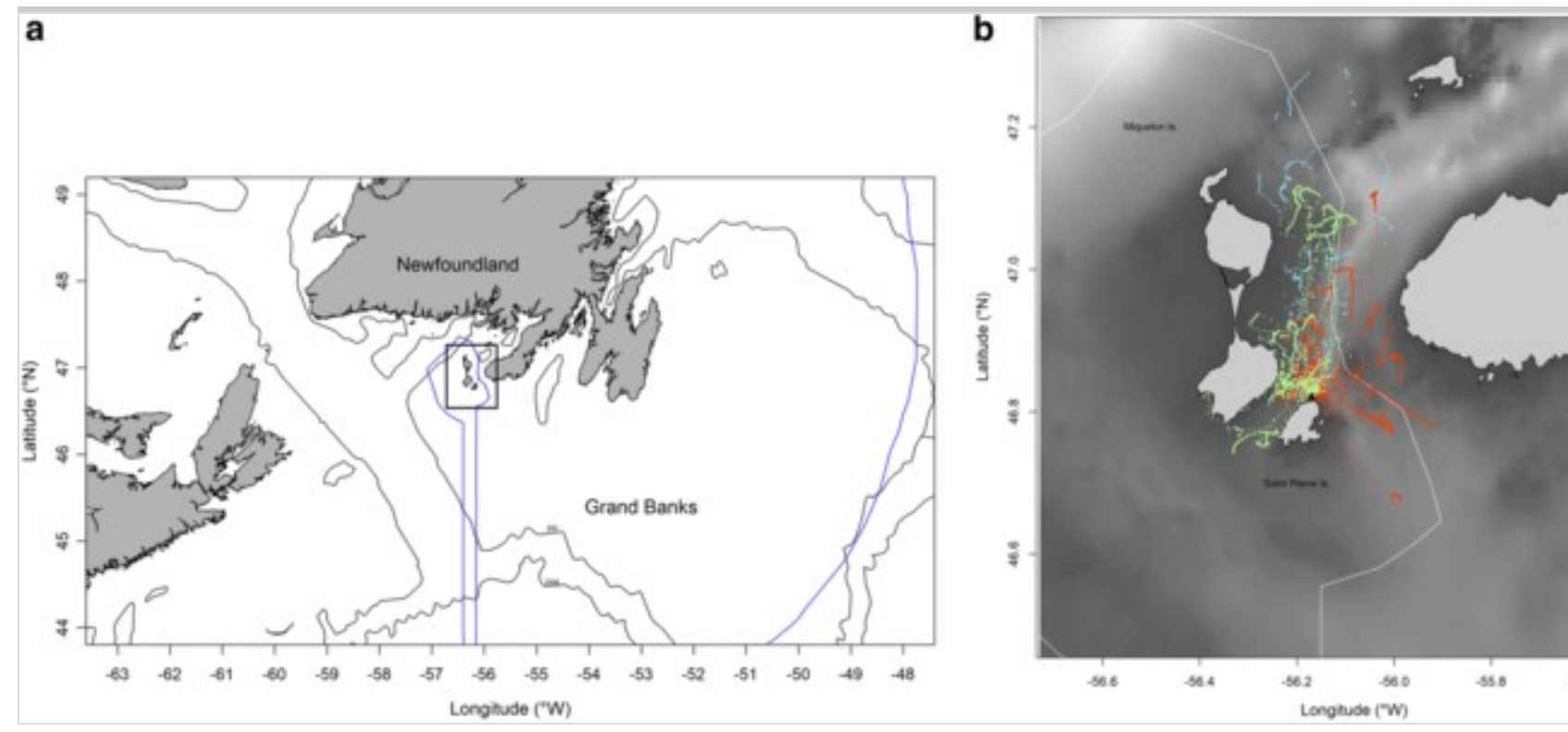

\section{Fig. 2}

Utilization distribution contours (25, 50 and 95\% UD) of foraging locations of three species of alcids (green: Razorbill, $n=5$; red: Common Murre, $n=6$; blue: Puffin, $n=4$ ) breeding on Grand Colombier Island (black triangle), Saint Pierre and Miquelon Archipelago, northwestern Atlantic overlapping with cumulated 
fishing effort [total length $(* 100 \mathrm{~m})$ of gillnets deployed per day and grid cell colour-coded according to a blue-purple scale] for salmon fishery in 2016 . Boundary of Exclusive Economic Zones is shown (blue line)

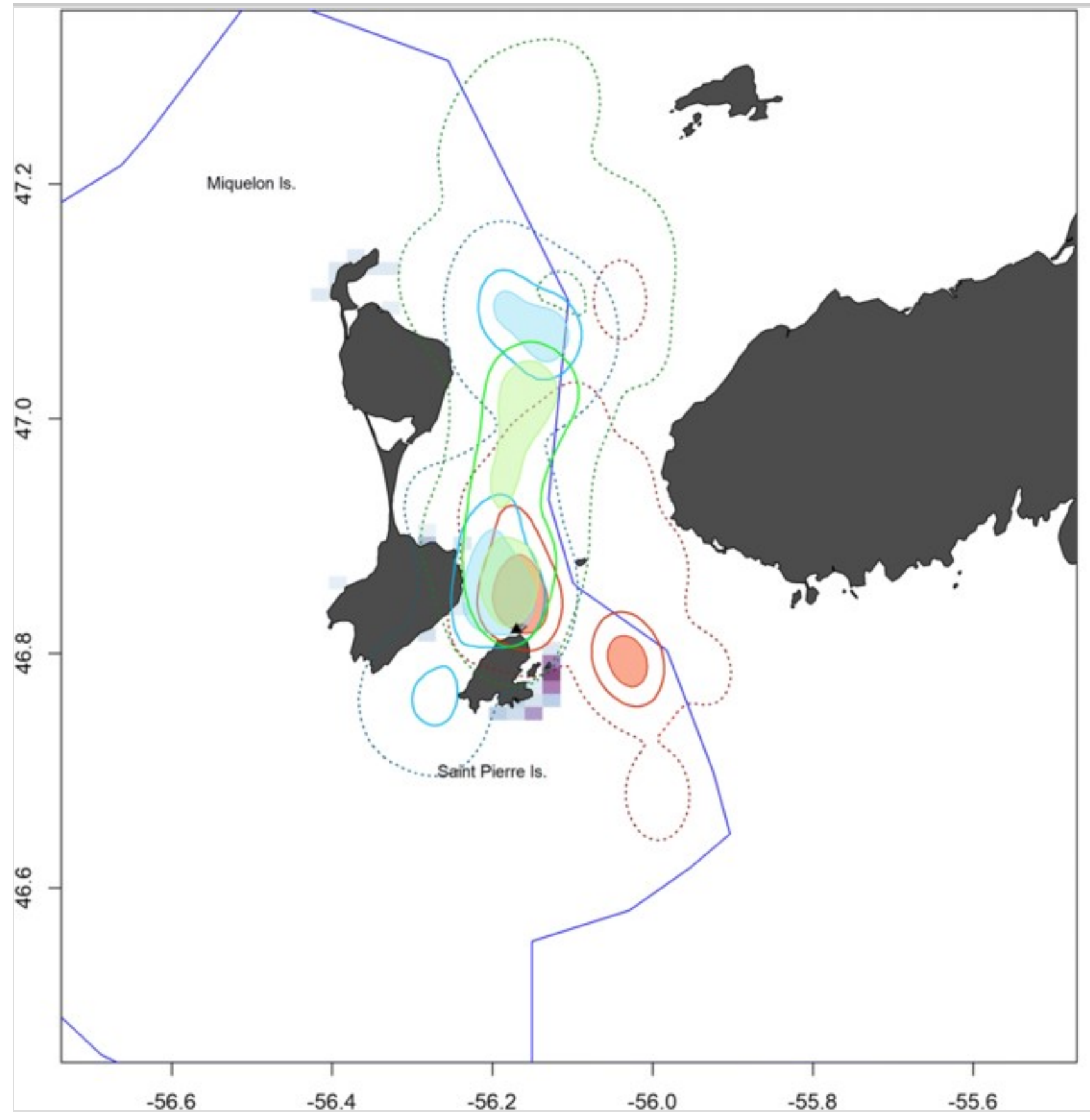

Table 2

Summary of foraging trip metrics for three species of sympatrically breeding alcids at $\mathrm{t}$ ] Pierre and Miquelon, northwestern Atlantic

\begin{tabular}{|l|l|l|l|l|l|}
\hline Species & $\begin{array}{l}\text { Number } \\
\text { of trips }\end{array}$ & $\begin{array}{l}\text { Maximum } \\
\text { foraging } \\
\text { distance } \\
(\mathbf{k m})\end{array}$ & Speed $(\mathbf{m} / \mathbf{s})$ & $\begin{array}{l}\text { Distance } \\
\text { covered } \\
(\mathbf{k m})\end{array}$ & $\begin{array}{l}\text { Trip } \\
\text { duration } \\
(\mathbf{h})\end{array}$ \\
\hline
\end{tabular}




\begin{tabular}{|c|c|c|c|c|c|}
\hline Species & $\begin{array}{l}\text { Number } \\
\text { of trips }\end{array}$ & $\begin{array}{l}\text { Maximum } \\
\text { foraging } \\
\text { distance } \\
(\mathbf{k m})\end{array}$ & Speed $(\mathrm{m} / \mathrm{s})$ & $\begin{array}{l}\text { Distance } \\
\text { covered }(\mathbf{k m})\end{array}$ & $\begin{array}{l}\text { Trip } \\
\text { duration (h) }\end{array}$ \\
\hline Razorbill & 28 & $\begin{array}{l}11.08 \pm \\
10.23 \\
(0.92-33.02)\end{array}$ & $\begin{array}{l}\text { Transit: } \\
7.30 \pm 14.21 \\
(0-90.96) \\
\text { Foraging: } \\
1.58 \pm 3.99 \\
(0-56.57)\end{array}$ & $\begin{array}{l}21.38 \pm 21.04 \\
(0.24-74.35)\end{array}$ & $\begin{array}{l}6.00 \pm 4.80 \\
(0.25-14.83)\end{array}$ \\
\hline $\begin{array}{l}\text { Common } \\
\text { Murre }\end{array}$ & 33 & $\begin{array}{l}9.85 \pm 7.28 \\
(1.30-33.61)\end{array}$ & $\begin{array}{l}\text { Transit: } \\
8.71 \pm 16.68 \\
(0-86.02) \\
\text { Foraging: } \\
1.44 \pm 3.19 \\
(0-48.51)\end{array}$ & $\begin{array}{l}19.57 \pm 16.15 \\
(1.13-71.64)\end{array}$ & $\begin{array}{l}6.76 \pm 4.47 \\
(0.33-17.58)\end{array}$ \\
\hline Puffin & 22 & $\begin{array}{l}19.52 \pm \\
14.36 * * \\
(2.02-51.44)\end{array}$ & $\begin{array}{l}\text { Transit: } \\
7.95 \pm 13.11 \\
(0.09-70.40) \\
\text { Foraging: } \\
1.90 \pm 4.73 \\
(0.06-55.08)\end{array}$ & $\begin{array}{l}36.36 \pm \\
30.27 * * \\
(1.24-111.71)\end{array}$ & $\begin{array}{l}9.35 \pm 7.41 \\
(1.17-30.00)\end{array}$ \\
\hline
\end{tabular}

${ }^{\mathrm{a} O n l y}$ complete trips were considered; $* * p<0.01$

\section{Foraging distribution}

The threshold and the HMM approaches were highly consistent in the identification of three zones used for foraging between SPM and Newfoundland (Fig. 3, Online Resource 1,2). These main foraging areas were located within $55 \mathrm{~km}$ from the breeding colony, on the coastal shelf nearby the eastern coast of Miquelon Island, and on the east of Saint Pierre Island (only for Common Murres). The HMM model appeared to adequately identify states (foraging versus transit), however, we suspect that the state sequence might sometimes have failed to capture the exact timing of the transitions. In some trips, the animal went through a transit phase between foraging behavior sequences, in which the movement was slower but still very directed. Although these periods are still arguably part of the foraging behavior, they might be attributed to the foraging state. The selected model estimated the transition probabilities as a function of sst for Razorbills (Table 3), of chla for Common Murres (Table 4) and of sst and chla for Puffins (Table 5). The results of all the models combining more than one covariate (except the model with an additive effect of sst and $\operatorname{chl} a$ ) were not selected (results not presented in Tables 3, 4, 5). Although for Razorbills the model combining sst and chla 
had a similar AIC than the model with only sst, we selected the later since slope parameters for chl $a$ were not significantly different from zero (their 95\% confidence intervals included zero). For Razorbills, the HMM predicted that the probability of switching from the foraging to the transit state started to increase with warmer waters (sst $>0.7$; Online Resource 2). For Common Murres, the HMM predicted that the probability of switching from the foraging state to the transit state started to increase in higher chla waters ( $>$ 0.5; Online Resource 3). Conversely, for Puffins the models predicted a higher probability of switching from the foraging state to the transit state in colder waters (sst $<-0.5)$ and in lower chl $a$ waters $(<-1$; Online Resource 4$)$.

\section{Fig. 3}

Example of utilization distribution contours a 25\% (solid lines), b 50\% (two dashed lines) and c) please change c) for c $75 \%$ (dotted lines) UD of foraging locations identified using two states hidden Markov models (yellow) and foraging locations identified using threshold (Wakefield et al. 2009) methods (red) for Common Murres breeding at Grand Colombier Island (black triangle), Saint Pierre and Miquelon Archipelago, northwestern Atlantic 


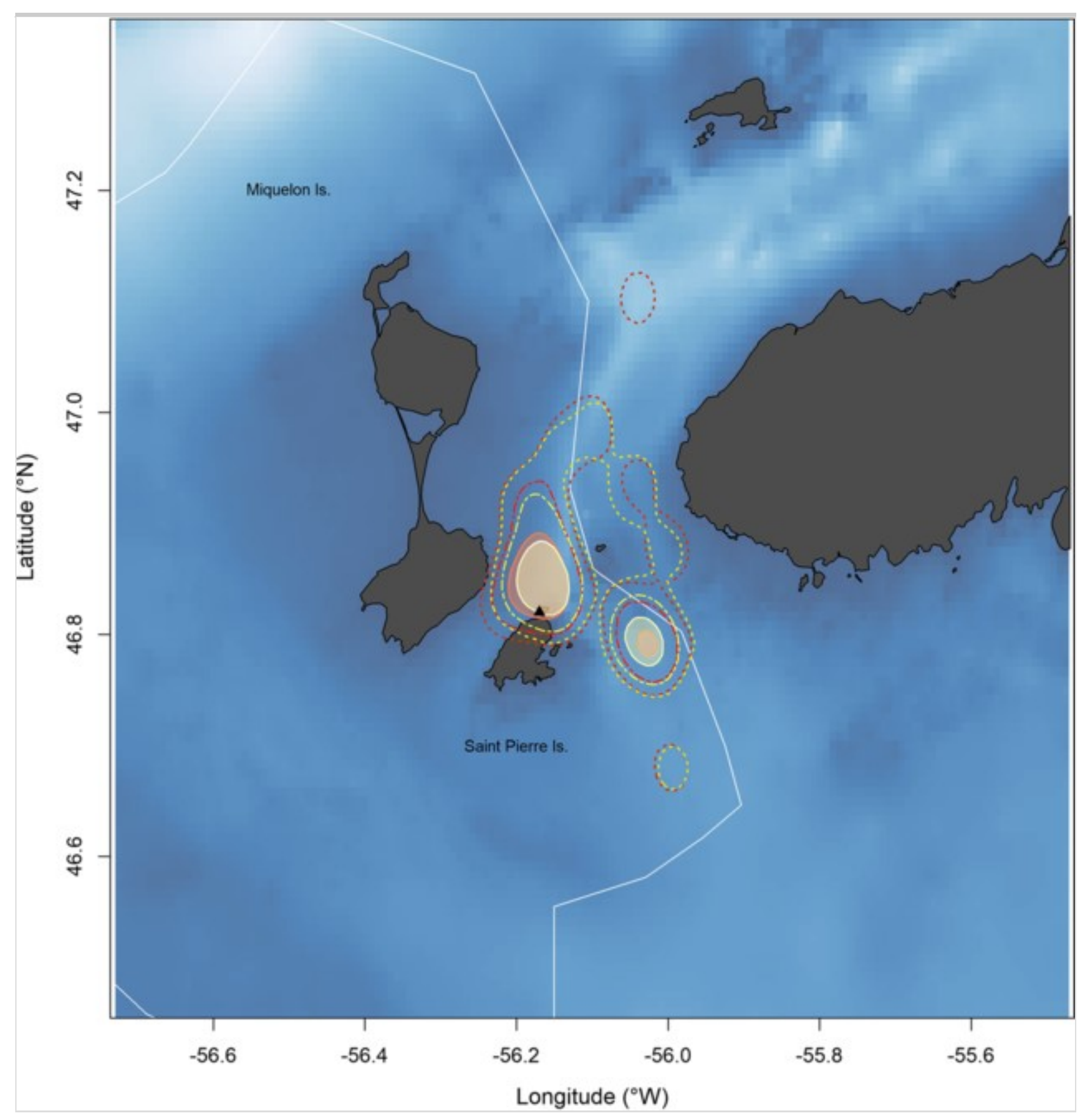

\section{Table 3}

Modelling the effect of environmental covariates (bathymetry: bathy, sea surface temperature: sst, chlorophyll a: $\operatorname{chl} a$ ) on the behavioral state of the Razorbills using two states hidden Markov models

\begin{tabular}{|l|l|l|l|l|l|}
\hline $\begin{array}{l}\text { Variables included } \\
\text { in the model }\end{array}$ & AIC & $\begin{array}{l}\boldsymbol{\Delta} \\
\text { AIC }\end{array}$ & $\begin{array}{l}\text { Log- } \\
\text { likelihood }\end{array}$ & $\begin{array}{l}\text { Slope } \\
\text { (foraging- } \\
\text { transit) }\end{array}$ & $\begin{array}{l}\text { Slope } \\
\text { (transit- } \\
\text { foraging) }\end{array}$ \\
\hline$\sim 1$ (no covariate) & - & 0 & 418.5 & & \\
\hline & 811.1 & 0 & & \\
\hline
\end{tabular}

Parameter estimates, along with 95\% CIs, for the best model as selected by AIC is indicated in bold 


\begin{tabular}{|c|c|c|c|c|c|}
\hline $\begin{array}{l}\text { Variables included } \\
\text { in the model }\end{array}$ & AIC & $\begin{array}{l}\Delta \\
\text { AIC }\end{array}$ & $\begin{array}{l}\text { Log- } \\
\text { likelihood }\end{array}$ & $\begin{array}{l}\text { Slope } \\
\text { (foraging-> } \\
\text { transit) }\end{array}$ & $\begin{array}{l}\text { Slope } \\
\text { (transit- > } \\
\text { foraging) }\end{array}$ \\
\hline $\begin{array}{l}\sim \text { B please chanqe } \\
\text { 'Bathy' for 'bathy' to } \\
\text { be consistent with the } \\
\text { table caption athy }\end{array}$ & $\overline{-} 808.6$ & 2.5 & 419.3 & $\begin{array}{l}0.077(- \\
0.315 \text { to } \\
0.470)\end{array}$ & $\begin{array}{l}0.245(- \\
0.150 \text { to } \\
0.640)\end{array}$ \\
\hline$\sim \mathrm{sst}$ & $\overline{814.0}$ & $-\overline{2.9}$ & 422.0 & $\begin{array}{l}0.419(0.107 \\
\text { to } 0.730)\end{array}$ & $\begin{array}{l}-0.001(- \\
\mathbf{0 . 3 0 5} \text { to } \\
\mathbf{0 . 3 0 4 )}\end{array}$ \\
\hline$\sim \operatorname{chl} a$ & $-\overline{812.1}$ & $\begin{array}{l}- \\
1.0\end{array}$ & 421.1 & $\begin{array}{l}0.129(- \\
0.168 \text { to } \\
0.425)\end{array}$ & $\begin{array}{l}-0.252(- \\
0.535 \text { to } \\
0.031)\end{array}$ \\
\hline$\sim \mathrm{sst}+\operatorname{chl} a$ & $\begin{array}{l}- \\
815.2\end{array}$ & $-\overline{4.1}$ & 424.6 & $\begin{array}{l}\text { sst } 0.429 \\
(0.122 \text { to } \\
0.736) \\
\text { chla } 0.148 \\
(-0.147 \text { to } \\
0.442)\end{array}$ & $\begin{array}{l}\text { sst } 0.100(- \\
0.220 \text { to } \\
0.419) \\
\text { chl } a-0.254 \\
(-0.544 \text { to } \\
0.037)\end{array}$ \\
\hline
\end{tabular}

Parameter estimates, along with $95 \%$ CIs, for the best model as selected by AIC is indicated in bold

\section{Table 4}

Modelling the effect of environmental covariates (bathymetry: bathy, sea surface temperature: sst, chlorophyll $a$ : $\operatorname{chl} a$ ) on the behavioral state of the Common Murres using two states hidden Markov models

\begin{tabular}{|c|c|c|c|c|c|}
\hline $\begin{array}{l}\text { Variables } \\
\text { included in the } \\
\text { model }\end{array}$ & AIC & $\begin{array}{l}\Delta \\
\mathbf{A I C}\end{array}$ & $\begin{array}{l}\text { Log- } \\
\text { likelihood }\end{array}$ & $\begin{array}{l}\text { Slope } \\
\text { (foraging-> } \\
\text { transit) }\end{array}$ & $\begin{array}{l}\text { Slope } \\
\text { (transit-> } \\
\text { foraging) }\end{array}$ \\
\hline$\sim 1$ (no covariate) & $\overline{2} 392.9$ & 0 & 1209.4 & & \\
\hline $\begin{array}{l}\sim \text { B please see } \\
\text { above } \\
\text { comment athy }\end{array}$ & $-\overline{2393.0}$ & 0.1 & 1211.5 & $\begin{array}{l}0.265(0.002 \\
\text { to } 0.527)\end{array}$ & $\begin{array}{l}0.083(- \\
0.121 \text { to } \\
0.287)\end{array}$ \\
\hline$\sim \mathrm{sst}$ & $\begin{array}{l}- \\
2396.2\end{array}$ & $-\overline{3.3}$ & 1213.1 & $\begin{array}{l}0.070(- \\
0.089 \text { to } \\
0.230)\end{array}$ & $\begin{array}{l}-0.285(- \\
0.537 \text { to } \\
0.032)\end{array}$ \\
\hline$\sim \operatorname{chl} a$ & $\overline{2401.0}$ & $\overline{8.2}$ & 1215.5 & $\begin{array}{l}\mathbf{0 . 2 2 4}(\mathbf{0 . 0 2 7} \\
\text { to } 0.420)\end{array}$ & $\begin{array}{l}-0.203(- \\
0.402 \text { to }- \\
0.009)\end{array}$ \\
\hline
\end{tabular}




\begin{tabular}{|l|l|l|l|l|l|}
\hline $\begin{array}{l}\text { Variables } \\
\text { included in the } \\
\text { model }\end{array}$ & AIC & $\begin{array}{l}\Delta \\
\text { AIC }\end{array}$ & $\begin{array}{l}\text { Log- } \\
\text { likelihood }\end{array}$ & $\begin{array}{l}\text { Slope } \\
\text { (foraging- } \\
\text { transit) }\end{array}$ & $\begin{array}{l}\text { Slope } \\
\text { (transit- }\end{array}$ \\
\hline foraging)
\end{tabular}

Parameter estimates, along with $95 \%$ CIs, for the best model as selected by AIC is indicated in bold

\section{Table 5}

Modelling the effect of environmental covariates (bathymetry: bathy, sea surface temperature: sst, chlorophyll $a: \operatorname{chl} a$ ) on the behavioral state of the Puffins using two states hidden Markov models

\begin{tabular}{|c|c|c|c|c|c|}
\hline $\begin{array}{l}\text { Variables } \\
\text { included in the } \\
\text { model }\end{array}$ & AIC & $\Delta \mathrm{AIC}$ & $\begin{array}{l}\text { Log- } \\
\text { likelihood }\end{array}$ & $\begin{array}{l}\text { Slope } \\
\text { (foraging- }> \\
\text { transit) }\end{array}$ & $\begin{array}{l}\text { Slope } \\
\text { (transit- > } \\
\text { foraging) }\end{array}$ \\
\hline$\sim 1$ (no covariate) & $\begin{array}{l}- \\
12592.6\end{array}$ & 0 & 6307.3 & & \\
\hline $\begin{array}{l}\sim \text { B please see } \\
\text { above } \\
\text { comment athy }\end{array}$ & $\frac{-}{12108.8}$ & 483.8 & 6067.4 & $\begin{array}{l}-0.108(- \\
0.196 \text { to }- \\
0.020)\end{array}$ & $\begin{array}{l}-0.445(- \\
0.598 \text { to }- \\
0.293)\end{array}$ \\
\hline$\sim \mathrm{sst}$ & $\begin{array}{l}- \\
11522.2\end{array}$ & 1070.4 & 5774.1 & $\begin{array}{l}-0.082(- \\
0.188 \text { to } \\
0.024)\end{array}$ & $\begin{array}{l}0.197(0.079 \\
\text { to } 0.316)\end{array}$ \\
\hline$\sim \operatorname{chl} a$ & $\overline{1}-\overline{1} 691.4$ & -98.8 & 6358.7 & $\begin{array}{l}0.112(0.010 \\
\text { to } 0.214)\end{array}$ & $\begin{array}{l}0.199(0.075 \\
\text { to } 0.323)\end{array}$ \\
\hline$\sim \operatorname{sst}+\operatorname{chl} a$ & $\overline{12804.4}$ & $-\overline{211.8}$ & 6417.2 & $\begin{array}{l}\text { sst } 0.005(- \\
0.100 \text { to } \\
\text { 0.109) } \\
\text { chla } 0.180 \\
(0.078 \text { to } \\
0.281)\end{array}$ & $\begin{array}{l}\text { sst } 0.278 \\
(\mathbf{0 . 1 5 9} \text { to } \\
\mathbf{0 . 3 9 7 )} \\
\text { chla } 0.304 \\
(\mathbf{0 . 1 7 6} \text { to } \\
\mathbf{0 . 4 3 2 )}\end{array}$ \\
\hline
\end{tabular}

Parameter estimates, along with $95 \%$ CIs, for the best model as selected by AIC is indicated in bold

AQ4

Spatial distribution of species and habitat differences

The three alcid species differed in their habitat distribution. Puffins and 
Razorbills had similar UDs since, whatever the UD considered, BA indices were not significantly lower than the null expectation for $25 \%, 50 \%, 75 \%$ or 95\% UDs (Table 6). Habitat distribution was dissimilar for Puffins and Common Murres or Razorbills and Common Murres, mainly for $25 \%$ or $95 \%$ UDs, as indicated by significant BA indices. However, the three species did not share the same foraging space as their UDOIs were significantly lower than the null expectation for $25 \%, 50 \%, 75 \%$ or $95 \%$ UDs (Table 7 ).

Table 6

Estimated overlap (Bhattacharyya's affinity-BA) in utilization distribution (UD) betwe sympatrically at Grand Colombier Island, Saint Pierre and Miquelon, northwestern Atlant

\begin{tabular}{|l|l|l|l|l|l|l|l|}
\hline $\begin{array}{l}\text { UD } \\
\mathbf{( \% )}\end{array}$ & \multicolumn{2}{|l|}{ Puffin/Razorbill } & \multicolumn{3}{|l|}{ Puffin/Common Murre } & & Razoi \\
\hline & $\begin{array}{l}\text { Observed } \\
\text { BA }\end{array}$ & $\begin{array}{l}\text { Randomized } \\
\text { BA }\end{array}$ & $\begin{array}{l}\boldsymbol{p} \\
\text { value }\end{array}$ & $\begin{array}{l}\text { Observed } \\
\text { BA }\end{array}$ & $\begin{array}{l}\text { Randomized } \\
\text { BA }\end{array}$ & $\begin{array}{l}\boldsymbol{p} \\
\text { value }\end{array}$ & $\begin{array}{l}\text { Obsei } \\
\text { BA }\end{array}$ \\
\hline 25 & 0.136 & 0.144 & 0.391 & 0.142 & 0.180 & 0.059 & 0.148 \\
\hline 50 & 0.257 & 0.278 & 0.281 & 0.312 & 0.336 & 0.212 & 0.327 \\
\hline 75 & 0.456 & 0.507 & 0.148 & 0.422 & 0.490 & 0.077 & 0.436 \\
\hline 95 & 0.688 & 0.744 & 0.138 & 0.558 & 0.703 & $\mathbf{0 . 0 2 3}$ & 0.552 \\
\hline
\end{tabular}

Bold indicates $p<0.05$, italics indicate $p<0.10$

\section{Table 7}

Estimated overlap (utilization distribution overlap index-UDOI) in utilization distribu1 species breeding sympatrically at Grand Colombier Island, Saint Pierre and Miquelon, no

\begin{tabular}{|c|c|c|c|c|c|c|c|}
\hline \multirow{2}{*}{$\begin{array}{l}\text { UD } \\
(\%)\end{array}$} & \multicolumn{3}{|c|}{ Puffin/Razorbill } & \multicolumn{3}{|c|}{ Puffin/Common Murre } & \multirow{2}{*}{$\begin{array}{l}\text { Razo! } \\
\text { Obseı } \\
\text { UDO] }\end{array}$} \\
\hline & $\begin{array}{l}\text { Observed } \\
\text { UDOI }\end{array}$ & $\begin{array}{l}\text { Randomized } \\
\text { UDOI }\end{array}$ & $\begin{array}{l}p \\
\text { value }\end{array}$ & $\begin{array}{l}\text { Observed } \\
\text { UDOI }\end{array}$ & $\begin{array}{l}\text { Randomized } \\
\text { UDOI }\end{array}$ & $\begin{array}{l}p \\
\text { value }\end{array}$ & \\
\hline 25 & 0.019 & 0.058 & 0.026 & 0.021 & 0.065 & 0.007 & 0.022 \\
\hline 50 & 0.072 & 0.141 & 0.018 & 0.111 & 0.169 & 0.045 & 0.121 \\
\hline 75 & 0.235 & 0.363 & 0.042 & 0.225 & 0.375 & $\mathbf{0 . 0 3 2}$ & 0.241 \\
\hline 95 & 0.643 & 0.832 & 0.068 & 0.491 & 0.965 & 0.014 & 0.505 \\
\hline
\end{tabular}

Bold indicates $p<0.05$, italics indicate $p<0.10$ 


\section{Overlap with fisheries}

The fishing effort for salmon during 2016 was fairly aggregated and occurred in only $0.53 \%$ of the grid cells for the area of SPM, and there was 9 143 maybe change for $9,143 \pm 10,364 \pm 10364 \mathrm{~m}$ of gillnets (min 540-max 40,140) deployed in these fishing areas (Fig. 2). Alcids overlapped differently with the fishery depending on species and UDs. The Razorbill exhibited the greatest overlap with fishing effort $(57,000 \mathrm{~m})$ for $95 \%$ UD (Fig. 4) and appeared to be more overlapping with the fishery with $1.4 \pm 1.1 \%$ of grid cells whatever the UD $(0-2.4 \%)$.

Fig. 4

Overlap between fishery for salmon and foraging locations of three species alcids: a cumulated fishing effort [total length $(* 100 \mathrm{~m})$ of gillnets deployed per day for each grid cell] and utilization distribution contours $(25,50,75$ and $95 \%$ UDs) and $\mathbf{b}$ percentage of UD grid cell with fishing activity 


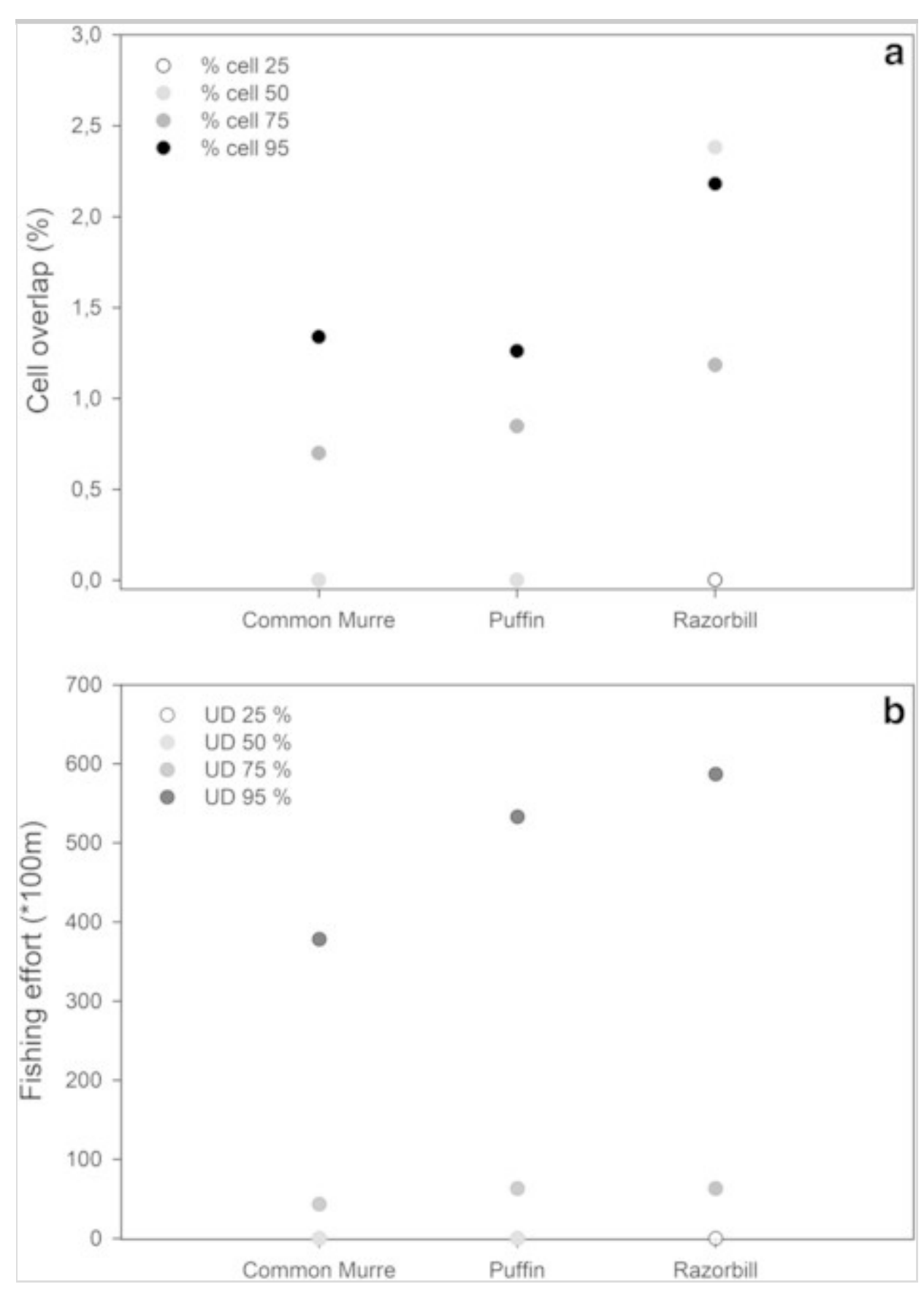

\section{Discussion}

\section{Spatial distribution}

None of the alcids (Razorbill, Common Murre and puffin) tracked at SPM exited the area between SPM and Newfoundland to reach a different foraging location. However, given the small sample sizes the results are based on, we recognize the limitations in the robustness of the conclusions. This is especially important when comparing overlaps and space use between species and the fishery. Although the three species fed in coastal waters during the study period, there was some spatial segregation between the species, since UDOI values clearly indicated little overlap in terms of space-use sharing. In 
addition, the utilization distribution of Common Murres differed from those of Razorbills and Puffins. Overall, the Common Murre foraged at closer distances from the colony that the two other species and the puffin foraged in more distant waters than the two other species. However, Razorbill and Puffin utilization distribution were relatively similar with two main foraging areas, one situated at the proximity of the colony and a second one $\approx 25-35 \mathrm{~km}$ north of the colony. We observed overlap in the habitat distribution only between Puffins and Razorbills, which likely could result in increased competition in spatial distribution. Segregation patterns among species, and namely chick diet and diving behavior, were explored in various colonies where alcids breed in sympatry (Elliott et al. 2010; Shoji et al. 2016; Pratte et al. 2017). It was generally hypothesized that different foraging behaviors evolved in sympatrically breeding alcid species sharing ecological similarities, as a mechanism allowing co-existence. Some examples include differences in diving and flying rates between Razorbills and Puffins (Shoji et al. 2015), differences in diving activity between Common Murres and Razorbills (Thaxter et al. 2010; Chimienti et al. 2017) or differences in diet dimension of the foraging niche between Puffins and Common Murres (Pratte et al. 2017). When alcids bred in sympatry they exhibited differences in preferred prey captured and loaded to their chick (i.e. Capelin Mallotus villosus or Sand Lance Ammodytes sp. in Newfoundland region; Pratte et al. 2017). In recent decades the proportion of favored prey in chick diet varied with annual changes (Pratte et al. 2017). We do not have diving data for the three alcid species at SPM, but field observations suggested that they all fed on the same preys (Sand Lance and Capelin) during the tracking period.

The behavioral models (threshold and HMM approaches) demonstrated a distinctive shift in behavior consistent with a transition between commuting (transit) and foraging (searching), returning to a central place (the breeding colony) between foraging excursions, typical of central-place foraging (Orians and Pearson 1979). The sea surface temperature and the chlorophyll a seemed to predict a part of the probability of switching between states (commuting vs foraging) for all species. The birds tended to shift from foraging to commuting with higher values of sea surface temperature (Razorbills) or in higher chlorophyll $a$ waters (Common Murres) or with higher values of sea surface temperature and chlorophyll (Puffins). Due to the absence of finescale environmental data (i.e. measured in situ by embedded devices deployed), we failed to characterize environmental conditions needed to supply alcids with sustainable food resources. However, the Gulf of St. 
Lawrence region is known for a high frontal activity thought to greatly influence biological production and species at different life stage (Legendre and Demers 1984; Legendre et al. 1985; Lesage et al. 2001; Le Fouest et al. 2005; Cyr and Larouche 2015). The SPM region is bathed by waters from Grand Bank and Canada's northwest shelf water brought by the inshore branch of the Labrador Current that bypasses Newfoundland (Chapman and Beardsley 1989; Han 2008). Recent work shows that the influence of the waters from the Gulf of St. Lawrence is very small at SPM (Rutherfort and Fennel 2018) but past measurements have shown episodic influences, mainly in summer (Petrie and Anderson 1983). Furthermore, the foraging areas identified for the three species are linked to highly structured and dynamic shallow waters (Lazure et al. 2018). The lack of salinity measurements during the experiment does not allow us to conclude on this point. Temperature measurements have shown hydrological conditions typical of the early summer when stratification is being established. The results suggest that the surface and bottom layers are decoupled and that the hydrological and biogeochemical properties of water bodies are different. Tidal currents follow bathymetry and are oriented in a north-south direction. During the study period they oscillated at semi-diurnal $(\sim 12.4 \mathrm{~h})$ and diurnal $(\sim 24-26 \mathrm{~h})$ periods (Lazure et al. 2018). The surface currents have a high temporal variability, while at the bottom they are directed northward (White and Hay 1994). This highly stratified and dynamic environment may probably impact foraging and diving behavior of alcids and further studies focusing on this link at a finer spatio-temporal scale should be beneficial.

\section{Overlap with fisheries}

Fisheries off Newfoundland's south coast and specifically the stretch between SPM and Newfoundland (Northwest Atlantic Fisheries Organization-NAFO sub division 3Ps) are characterized by small polyvalent vessels targeting Snow Crabs (Chionoecetes opilio), Lobster (Homarus americanus), Cod, Scallops (Placopecten magellanicus and Chlamys islandica) and Sea Cucumber (Cucumaria frondosa). These species are fished using gillnets, longlines, traps and dredge.

The gillnet fisheries represent the largest threat to the alcids foraging in the SPM-Newfoundland area, especially gillnets targeting Atlantic cod (Benjamins et al. 2008; Hedd et al. 2016). In recent years, the observed local bycatch rate appeared to be low compared to the regional rates reported.

Nonetheless, recent studies highlighted that diving seabirds (Murres and other 
alcids) are at risk of incidental capture in gillnet fisheries that operate close to breeding colonies in summer (Davoren 2007; Ellis et al. 2013; Žydelis et al. 2013; Hedd et al. 2016). Regular et al. (2010) demonstrated that gillnet fisheries were among significant factors driving changes in population dynamics in recent decades.

Our results highlighted that alcids breeding at SPM overlap with the fishing effort of gillnet targeting salmon and suggested that bycatch could possibly occur for these populations. There are no official records for incidental capture of alcids in SPM fisheries, and very few seabird bycatch has been reported so far. Gillnets targeting Atlantic cod, even if not operating during the study period in the SPM EEZ, should be considered as a greater potential threat for this community at local scale. Further studies are needed to assess the incidental seabird catch associated with all fisheries operating within the SPM EEZ, including recreational fisheries. The implementation of a sampling protocol of recording and reporting of seabird bycatch should be prioritized in the near future.

\section{Conclusion}

We found evidence for some spatial segregation in foraging areas at-sea in an alcid community breeding in the SPM archipelago. Foraging habitats were partly determined by sea surface temperatures with birds adopting a foraging behavior when sea surface temperature decreased. All the three species overlapped with gillnet fishery targeting Atlantic salmon. Additional telemetry studies are needed to further understand alcids movements during the entire breeding period and the non-breeding period, and estimate the degree of overlap with other fisheries, as potential threats for populations. In addition, to fully comprehend the foraging strategies of the three species breeding in the SPM area, fine-scale diving data combined with diet and prey studies are needed. This will contribute to improve our understanding of the subpopulations of alcids utilizing this area and allow better conservation of the species in the Newfoundland region with transboundary efforts.

AQ5

\section{Publisher's Note}

Springer Nature remains neutral with regard to jurisdictional claims in published maps and institutional affiliations.

\section{Acknowledgements}


The authors are grateful to Richard Martin (Office National de la Chasse et de la Faune Sauvage-ONCFS), Jean Bouilleau (ONCFS) for their help in field operations and Lina Gouichiche for a preliminary data exploration. We thank K. Heerah and S. Bertrand for helpful advice on the HMM analyses. We thank two anonymous referees for constructive comments on earlier drafts.

\section{Author contributions}

Study design: HL, CB, KD fieldwork: HL, CB, KD, BL, data analysis and processing: KD, KD wrote the text and all authors edited and revised the manuscript, gave final approval for publication and agreed to be held accountable for the content therein.

\section{Funding}

The study was funded by Direction des Territoires, de l'Alimentation et de la Mer de Saint Pierre et Miquelon (FR) and the European Program BEST 2.0.

\section{Data availability}

The datasets generated during and/or analysed during the current study are available in the Movebank repository, https://www.movebank.org /panel_embedded_movebank_webapp, Alcids Tracking breeding at Saint Pierre and Miquelon, North Atlantic, France, ID: 773585900

Compliance with ethical standards

Ethical approval All applicable international, national, and/or institutional guidelines for the care and use of animals were followed. All procedures performed in studies involving animals were in accordance with the ethical standards of the institution or practice at which the studies were conducted. All capture and handling procedures were in accordance with the permits provided by the competent Authority (French Ministry of Environment, Energy and Sea).

\section{Electronic supplementary material}

Below is the link to the electronic supplementary material.

Supplementary material 1 (DOCX $502 \mathrm{~kb})$

\section{References}


Benjamins S, Kulka DW, Lawson J (2008) Incidental catch of seabirds in Newfoundland and Labrador gillnet fisheries, 2001-2003. Endanger Species Res 5:149-160

Breed GA, Bowen W, McMillan J, Leonard ML (2006) Sexual segregation of seasonal foraging habitats in a non-migratory marine mammal. Proc $\mathrm{R}$ Soc Lond B Biol Sci 273:2319-2326

Burnham KP, Anderson DR (2002) Model selection and multimodel inference: a practical information-theoretic approach. New York AQ6

Calenge C (2006) The package adehabitat for the R software: a tool for the analysis of space and habitat use by animals. Ecol Model 197:516-519

Chapman DC, Beardsley RC (1989) On the origin of shelf water in the middle atlantic bight. J Phys Oceanogr 19:384-391

Chimienti M, Cornulier T, Owen E et al (2017) Taking movement data to new depths: inferring prey availability and patch profitability from seabird foraging behavior. Ecol Evol 7:10252-10265. https://doi.org/10.1002 /ece3.3551

Croxall JP, Butchart SHM, Lascelles B et al (2012) Seabird conservation status, threats and priority actions: a global assessment. Bird Conserv Int 22:1-34

Cyr F, Larouche P (2015) Thermal fronts atlas of canadian coastal waters. Atmos Ocean 53:212-236. https://doi.org/10.1080/07055900.2014.986710

Davoren GK (2007) Effects of gill-net fishing on marine birds in a biological hotspot in the Northwest Atlantic. Conserv Biol 21:1032-1045

Davoren GK, Montevecchi WA (2003) Consequences of foraging trip duration on provisioning behaviour and fledging condition of common murres Uria aalge. J Avian Biol 34:44-53

Elliott KH, Shoji A, Campbell KL, Gaston AJ (2010) Oxygen stores and foraging behavior of two sympatric, planktivorous alcids. Aquat Biol 8:221-235. https://doi.org/10.3354/ab00236 
Ellis JI, Wilhelm SI, Hedd A et al (2013) Mortality of migratory birds from marine commercial fisheries and offshore oil and gas production in Canada. Avian Conserv Ecol 8:2. https://doi.org/10.5751 /ACE-00589-080204

Fieberg J, Kochanny CO (2005) Quantifying home-range overlap: the importance of the utilization distribution. J Wildl Manag 69:1346-1359

Han G (2008) Seasonal variability of the labrador current and shelf circulation off Newfoundland. J Geophys Res Oceans 113:C10

Hedd A, Regular PM, Wilhelm SI et al (2016) Characterization of seabird bycatch in eastern Canadian waters, 1998-2011, assessed from onboard fisheries observer data. Aquat Conserv Mar Freshw Ecosyst 26:530-548. https://doi.org/10.1002/aqc.2551

Jonsen ID, Flenming JM, Myers RA (2005) Robust state-space modeling of animal movement data. Ecology 86:2874-2880

Langrock R, King R, Matthiopoulos J et al (2012) Flexible and practical modeling of animal telemetry data: hidden Markov models and extensions. Ecology 93:2336-2342. https://doi.org/10.1890/11-2241.1

Lazure P, Le Cann B, Bezaud M (2018) Large diurnal bottom temperature oscillations around the Saint Pierre and Miquelon archipelago. Sci Rep 8:13882. https://doi.org/10.1038/s41598-018-31857-w

Le Fouest V, Zakardjian B, Saucier FJ, Starr M (2005) Seasonal versus synoptic variability in planktonic production in a high-latitude marginal sea: the Gulf of St. Lawrence (Canada). J Geophys Res Oceans 110:C09012. https://doi.org/10.1029/2004jc002423

Legendre L, Demers S (1984) Towards dynamic biological oceanography and limnology. Can J Fish Aquat Sci 41:2-19. https://doi.org/10.1139 /f84-001

Legendre L, Demers S, Therriault J, Boudreau C (1985) Tidal variations in the photosynthesis of estuarine phytoplankton isolated in a tank. Mar Biol 88:301-309. https://doi.org/10.1007/BF00392591 
Lesage V, Hammill MO, Kovacs KM (2001) Marine mammals and the community structure of the Estuary and Gulf of St Lawrence, Canada: evidence from stable isotope analysis. Mar Ecol Prog Ser 210:203-221. https://doi.org/10.3354/meps210203

Lewison RL, Crowder LB, Wallace BP et al (2014) Global patterns of marine mammal, seabird, and sea turtle bycatch reveal taxa-specific and cumulative megafauna hotspots. Proc Natl Acad Sci 111:5271-5276 AQ7

Linnebjerg JF, Fort J, Guilford T et al (2013) Sympatric breeding auks shift between dietary and spatial resource partitioning across the annual cycle. PLoS One 8(8):e72987

Lormée H, Delord K, Letournel B (2008) Dénombrement des oiseaux marins nicheurs sur l'Ile du Grand Colombier (Saint Pierre and Miquelon). Unpublished ONCFS Report, pp 23

Lormée H, Delord K, Letournel B, Barbraud C (2012) Population survey of Leach's storm-petrels breeding atGrand Colombier Island, Saint-Pierre and Miquelon archipelago. Wilson J Ornithol 124:245-252

Lormée H, Barbraud C, Letournel B (2015) Etude des populations d'oiseaux marins nicheurs sur l'Ile du Grand Colombier (Saint Pierre and Miquelon). Direction de l'Agriculture et de la Forêt, Saint Pierre, Saint Pierre et Miquelon. Unpublished ONCFS Report, pp 24

Michelot T, Langrock R, Patterson TA (2016) moveHMM: an R package for the statistical modelling of animal movement data using hidden Markov models. Methods Ecol Evol 7:1308-1315. https://doi.org/10.1111 /2041-210X.12578

Oppel S, Bolton M, Carneiro APB et al (2018) Spatial scales of marine conservation management for breeding seabirds. Mar Policy 98:37-46. https://doi.org/10.1016/j.marpol.2018.08.024

Orians GH, Pearson NE (1979) On the theory of central place foraging. In: Horn DJ, Mitchell R, Stair GR (eds) Columbus. Ohio State University Press, Ohio, pp 155-177 
Patterson TA, Basson M, Bravington MV, Gunn JS (2009) Classifying movement behaviour in relation to environmental conditions using hidden Markov models. J Anim Ecol 78:1113-1123. https://doi.org/10.1111 /j.1365-2656.2009.01583.x

Petrie B, Anderson C (1983) Circulation on the Newfoundland continental shelf. Atmos Ocean 21:207-226

Phillips RA, Wakefield ED, Croxall JP et al (2009) Albatross foraging behaviour: no evidence for dual foraging, and limited support for anticipatory regulation of provisioning at South Georgia. Mar Ecol Prog Ser 391:279-292

Piatt J, Nettleship D (1987) Iincidental catch of marine birds and mammals in fishing netts off Newfoundland, Canada. Mar Pollut Bull 18:344-349. https://doi.org/10.1016/S0025-326X(87)80023-1

Pinheiro J, Bates D, DebRoy S et al (2013) nlme: Linear and Nonlinear Mixed Effects Models. R package version 3.1-117

Pratte I, Robertson GJ, Mallory ML (2017) Four sympatrically nesting auks show clear resource segregation in their foraging environment. Mar Ecol Prog Ser 572:243-254. https://doi.org/10.3354/meps12144

R Core Team (2018) R: A language and environment for statistical computing [Internet]. Vienna, Austria: R Foundation for Statistical Computing. https://www.R-project.org/

AQ8

Regular PM, Robertson GJ, Montevecchi WA et al (2010) Relative importance of human activities and climate driving common murre population trends in the Northwest Atlantic. Polar Biol 33:1215-1226

Rodway MS, Montevecchi WA (1996) Sampling methods for assessing the diets of Atlantic puffin chicks. Mar Ecol Prog Ser 144:41-55. https://doi.org/10.3354/meps144041

Rutherfort K, Fennel K (2018) Diagnosing transit times on the northwestern North Atlantic continental shelf. Ocean Sci 14:1207-1221 
Shoji A, Elliott K, Fayet A et al (2015) Foraging behaviour of sympatric razorbills and puffins. Mar Ecol Prog Ser 520:257-267. https://doi.org $/ 10.3354 /$ meps 11080

Shoji A, Aris-Brosou S, Elliott KH (2016) Physiological constraints and dive behavior scale in tandem with body mass in auks: a comparative analysis. Comp Biochem Physiol Mol Integr Physiol 196:54-60. https://doi.org/10.1016/j.cbpa.2016.02.023

Thaxter CB, Wanless S, Daunt F et al (2010) Influence of wing loading on the trade-off between pursuit-diving and flight in common guillemots and razorbills. J Exp Biol 213:1018-1025. https://doi.org/10.1242/jeb.037390

Wakefield ED, Phillips RA, Matthiopoulos J (2009) Quantifying habitat use and preferences of pelagic seabirds using individual movement data: a review. Mar Ecol Prog Ser 391:165-182

Wanless S, Harris M, Morris J (1990) A comparison of feeding areas used by individual common murres (Uria aalge), razorbills (Alca torda) and an Atlantic puffin (Fratercula arctica) during the breeding season. Colon Waterbirds 16-24

AQ9

Zucchini W, Raubenheimer D, MacDonald IL (2008) Modeling time series of animal behavior by means of a latent-state model with feedback. Biometrics 64:807-815. https://doi.org/10.1111/j.1541-0420.2007.00939.x

Zuur AF, Ieno EN, Elphick CS (2010) A protocol for data exploration to avoid common statistical problems. Methods Ecol Evol 1:3-14. https://doi.org/10.1111/j.2041-210X.2009.00001.x

Žydelis R, Bellebaum J, Ísterblom H et al (2009) Bycatch in gillnet fisheries - an overlooked threat to waterbird populations. Biol Conserv 142:1269-1281

Žydelis R, Small C, French G (2013) The incidental catch of seabirds in gillnet fisheries: a global review. Biol Conserv 162:76-88 